\title{
Edwarda Goldsmitha krytyka nowożytnego paradygmatu postępu naukowo-technicznego
}

\author{
Anita Ganowicz-Bączyk \\ Wydział Filozofii Chrześcijańskiej \\ Uniwersytet Kardynała Stefana Wyszyńskiego \\ Instytut Ekologii i Bioetyki, ul. Wóycickiego 1/3, 01-938 Warszawa, a.ganowicz@uksw.edu.pl
}

\begin{abstract}
Streszczenie
Etyka środowiskowa znajduje wielu zwolenników wśród filozofujących przyrodników. Interesujący głos w tym temacie zabiera Edward Goldsmith, który na bazie Hipotezy Gai Jamesa Lovelocka zbudował etykę biosferyczną. Goldsmith krytycznie odnosi się do paradygmatu nowożytnego przyrodoznawstwa, uznając go za błędny oraz kryzysotwórczy w relacji ludzkości z całą ekosferą. Za paradygmatem tym stoi określone rozumienie postępu ludzkości oraz konkretne założenia ontologiczne, aksjologiczne i etyczne (np. darwinizm społeczny, utylitaryzm etyczny). Goldsmith nazywa etykę stojącą za tymi przekonaniami etyką technosferyczną, poddaje krytyce jej założenia i przeciwstawia jej etykę biosferyczną. Jego zdaniem, etyka sprzyjająca realizacji celów Gai była obecna w pierwotnych społecznościach ludzkich. Wymagała ona od człowieka utrzymywania porządku kosmicznego, a zarazem dobrostanu jednostki i całej społeczności, poprzez podążanie właściwą Drogą, tzn. przestrzeganie określonych obowiązków oraz zachowań, szczególnie w obszarze rytuałów i życia religijnego. Dlatego, jak przekonuje Goldsmith, skutecznie chronić porządek ekosfery można wyłącznie w sposób religijny. Nie ma, jego zdaniem, bardziej niemoralnego przedsięwzięcia niż postęp, który wiedzie systematycznie do zastąpienia biosfery przez technosferę. Rozwój oparty o technikę prowadzi w sposób nieunikniony do destrukcji. Jeśli chcemy przetrwać jako gatunek - musimy powrócić do etyki biosferycznej.
\end{abstract}

\section{Stowa kluczowe}

etyka środowiskowa, ekocentryzm, holizm, biosfera, człowiek, Edward Goldsmith, hipoteza Gai

\section{Wstęp}

Rozwijająca się intensywnie od lat 70. XX w. etyka środowiskowa znajduje wielu zwolenników, szczególnie wśród filozofów i filozofujących przyrodników. Wypracowano szereg stanowisk, które różnią się znacząco na płaszczyźnie ontologicznej, antropologicznej i aksjologicznej. Jednoczy je zaś jeden wspólny cel: takie ułożenie stosunków człowieka z przyrodą, aby sprzyjały one zachowaniu biosfery w jej różnorodności oraz w stanie przyjaznym dla człowieka. Wszystkie propozycje etyki środowiskowej w jakimś zakresie starają się zdemaskować przyczyny, które doprowadziły do zdegradowania środowiska przyrodniczego oraz do gwałtownego zanikania bioróżnorodności. Interesujący głos w tym temacie 
zabiera Edward Goldsmith, twórca etyki biosferycznej.

\section{Biosfera według Edwarda Goldsmitha}

Edward Goldsmith (1928-2009), francuski przyrodnik żydowskiego pochodzenia, pisarz oraz filozof, jest jednym z przedstawicieli ekologii głębokiej, nurtu zainicjowanego w 1973 roku przez norweskiego filozofa Arne Næssa (1912-2009) (Næss 1973: 95-100). Etyka biosferyczna stanowi próbę uzasadnienia podstawowych twierdzeń głębokiej ekologii. Uzasadnienia tego Goldsmith dokonuje poprzez odwołanie się do Hipotezy Gai, systemowej teorii biosfery wypracowanej przez brytyjskiego chemika i klimatologa Jamesa Lovelocka (ur. 1919) oraz amerykańską biolog Lynn Margulis (1938-2011), zaprezentowanej w książce Gaia: A New Look at Life on Earth (1979 r.) (Lovelock 2003). Z teorii Gai Lovelocka Goldsmith wyprowadza warstwę filozoficzną i światopoglądową, a następnie system etyki i praktycznych dyrektyw postępowania.

Gaja (od imienia greckiej bogini Ziemi) to imię, jakie J. Lovelock nadał planecie Ziemia, rozumianej przez niego jako swoisty superorganizm. Panorganizm ten powstał na skutek globalnego współdziałania wszystkich organizmów żywych, oceanów, powietrza i powierzchniowych warstw skał (Lovelock 2003: 8). Zdaniem Lovelocka, fakty odkrywane na temat funkcjonowania systemu ziemskiego wskazują na to, że Gaja jako całość zachowuje się celowo. Jej celem jest podtrzymywanie swego istnienia, czyli istnienia życia na Ziemi. Gaja stanowi skomplikowany system, który utrzymuje swą dynamiczną stabilność dzięki przetwarzaniu informacji dopływających do systemu oraz za pomocą wielu regulacyjnych mechanizmów ujemnych i dodatnich sprzężeń zwrotnych. Spośród tych mechanizmów znamy już wiele, ale jeszcze nie wszystkie rozpoznajemy (Por. Lovelock 2003: 63-77).

Ziemia nie jest więc jedynie (czy aż) środowiskiem życia organizmów, areną, na której rozgrywa się życie, ale sama jest czymś na kształt organizmu, biogeochemicznego bytu.
Organizm ten dysponuje mechanizmami samoregulacji, natomiast jego części składowe (osobniki, gatunki, ekosystemy, biomy) są mniej lub bardziej ważnymi organami całości. Za utrzymanie homeostazy systemu, czyli za tworzenie i zachowanie warunków dla jego istnienia i rozwoju, odpowiadają zjawiska i mechanizmy zachodzące naturalnie w biosferze. Mechanizmy samoregulacji biosfery są aktywną siłą, która wytwarza w procesie ewolucji organizmy i gatunki (Por. Bonenberg 1992: 93-94). W tym sensie Gaja zachowuje się w sposób właściwy indywidualnym organizmom: tak jak one posiada zdolności adaptacji i samoregulacji służącej podtrzymaniu wewnętrznej stabilności, a tym samym własnego istnienia.

Na bazie modelu Ziemi-Gai Jamesa Lovelocka Edward Goldsmith zbudował etykę biosferyczną (biospheric ethic). Podstawowe twierdzenia etyki Goldsmitha zostały przez niego przedstawione w tekście The Way: An Ecological Worldview (Goldsmith 1992). Decydujące dla jego koncepcji okazały się także poglądy amerykańskiego ekologa, Eugene Oduma (1913-2002), za którym Goldsmith przyjmuje, że przyroda jest zorganizowana hierarchicznie. Hierarchiczność ta jest obserwowalna zarówno na poziomie ponadosobniczym, np. regiony biogeograficzne, biomy, krajobrazy, ekosystemy, wspólnoty biotyczne, populacje, jak i na poziomie organizmu, np. układy narządów, narządy, tkanki, komórki, organelle komórkowe, molekuły. Szczególnie istotny dla ekologii jest najwyższy poziom organizacyjny tej hierarchii. Ma on znaczenie decydujące, gdyż całość sprawuje niejako kontrolę nad elementami wchodzącymi w jej skład. Pogląd na relacje między całością i jej elementami wyraźnie nawiązuje do wypracowanej przez austriackiego biologa i filozofa Ludwika von Bertalanffy'ego (1901-1972) teorii systemów (Bertalanffy 1984). W przeciwieństwie do poglądów redukcjonistycznych (np. Dawkins 1996), Goldsmith uważa, że istoty żywe nie są samolubne czy indywidualistyczne w stabilnej społeczności i w stabilnym ekosystemie. Przede wszystkim ze swej natury 
dążą one do podtrzymania integralności i stabilności hierarchii ekosfery - dobrostan żywych organizmów zależy ostatecznie od dobrostanu rodzin, wspólnot, społeczeństw, populacji, ekosystemów, których stanowią część, oraz od stanu całej ekosfery (Web-o2).

Dla Goldsmitha idea mówiąca, że wszystkie procesy życiowe w stabilnym ekosystemie są ukierunkowane na cel, stanowi zasadniczą cechę prawdziwego holistycznego światopoglądu (Web-o2). Dlatego też szczególnie mocno eksponuje on takie cechy ekosystemów, jak ich uporządkowany charakter oraz ewolucyjność i teleologiczność. Ewolucja jest przez niego rozumiana jako droga, na której możliwe jest osiągnięcie celu każdego ożywionego bytu, a przede wszystkim celu Gai, jakim jest stabilność systemu (systemów) (Por. Bonenberg 1992: 101).

Goldsmith zauważa, że w początkowym okresie swego rozwoju ekologia stanowiła reakcję na redukcjonistyczny i mechanistyczny paradygmat nauk przyrodniczych. Przywracała rozumienie ekosfery jako uporządkowanego bytu, co wyrażało się w fundamentalnej dla niej zasadzie, głoszącej „równowagę w przyrodzie”. Ale z biegiem czasu ekologowie zaczęli dostosowywać się do obowiązującego w szeroko rozumianych naukach biologicznych paradygmatu naukowego, z jednej strony racjonalizując rozwój czy postęp, a z drugiej - kwestionując takie podstawowe zasady uprawianej przez siebie dyscypliny, jak: 1) koncepcja równowagi w przyrodzie, 2) zasada głosząca, że sukcesja ekologiczna prowadzi do klimaksu (końcowego, stabilnego stadium rozwojowego biocenozy), 3) pogląd, że całość jest czymś więcej niż sumą części składowych oraz 4) reguła mówiąca, że złożoność wiedzie do stabilności (Web-o3).

Jak wspomniano, według Goldsmitha do istoty Gai należy porządek. Innym słowem, jakiego można użyć na określenie porządku w odniesieniu do procesów życiowych, jest celowość. Porządek i celowość są dla Goldsmitha nierozdzielalne. Porządek stanowi wyraz ograniczeń nakładanych na całość przez części. Z drugiej strony, części wypełniają swoje funkcje wobec systemów, których część stanowią, podtrzymując ich integralność i stabilność. Dla Goldsmitha oczywiste jest, że świat jest uporządkowany. Gdyby nie był, nie moglibyśmy go zrozumieć, poznać, czy sobie wyobrazić. Żadna nauka nie miałaby racji bytu. Porządek jest utrzymywany poprzez ewolucję oraz zachodzące w jej ramach procesy życiowe. Indywidualistyczne systemy zostają w konsekwencji procesów adaptacyjnych zorganizowane, zróżnicowane oraz wyspecjalizowane w wypełnianiu rozmaitych funkcji w ramach całego systemu. Rywalizacja ustępuje współpracy, dzięki czemu system staje się stabilniejszy. Porządek implikuje organizację, zróżnicowanie, specjalizację, kooperację i stabilność świata ożywionego - na każdym z poziomów organizacyjnych Gai (Web-o3). Goldsmith podkreśla, że stabilny system nie jest nastawiony przeciw zmianom, ale raczej nakierowany na ich unikanie. Zmiana nie jest czymś pożądanym, ale czasem okazuje się konieczna w celu zapobieżenia zmianom większym i bardziej destrukcyjnym. Wynika z tego, że stabilność to nie to samo, co niezmienność. Niezmienny system nie jest stabilny, gdyż nie jest zdolny do przystosowywania się do zmian w środowisku. Tymczasem nauka i ekologia głównego nurtu akcentują fakt ciągłych zmian; w tym świetle rozwój ekonomiczny oraz postęp wydają się procesami naturalnymi. Niemniej, jak podkreśla Goldsmith, to stabilność, a nie zmienność jest najbardziej uderzającą cechą świata ożywionego (Web-o3).

Postęp ekonomiczny nie może jednak następować bez niszczenia tego krytycznego porządku przyrody. Dlatego Goldsmitha nie dziwi usprawiedliwianie i racjonalizowanie rozwoju technosfery poprzez odchodzenie nowożytnej nauki od poglądu o istnieniu porządku rządzącego światem. Co więcej, zauważa, współcześni autorzy - zainspirowani Karolem Marksem - nie poprzestają na zaprzeczeniu uporządkowanego charakteru przyrody, ale rozciągają to stanowisko na rzeczywistość ludzką. Twierdzą mianowicie, iż człowiek nie ma wrodzonej 
natury, ale jest wytworem procesów historyczno-społecznych. Nawet nieprzychylni marksizmowi socjobiolodzy, z Edwardem O. Wilsonem na czele, wskazują, że człowiek może się zaadaptować do życia w niemal każdym społeczeństwie i środowisku. W ten sposób racjonalizowane jest przekonanie, że historia jest tylko serią chaotycznych, niepowiązanych ze sobą zdarzeń, a nie przyczynowo-skutkowo uporządkowanym procesem (Web-03, por. Wilson 2000: 292-296).

Wbrew opisanym trendom, Goldsmith podkreśla, że ekosfera to podlegający jednemu porządkowi, czasoprzestrzenny byt, a jej struktura i funkcje podlegają prawom, które stosują się zarówno do organizmów biologicznych, pierwotnych wspólnot, społeczeństw, ekosystemów oraz samej Gai (Web-o3).

\section{Paradygmat naukowo-techniczny jako przyczyna błędnego obrazu przyrody}

W sposobie rozumienia przyrody Goldsmith daleki jest od obowiązującego od co najmniej czasów Kartezjusza nowożytnego paradygmatu naukowo-technicznego, w którym przyroda postrzegana jest jako swego rodzaju korelat nauk matematyczno-przyrodniczych, opisywana jest w kategoriach mechanistycznych, wyjaśniana w sposób deterministyczny, oraz pozbawiana jakichkolwiek znamion celowości (ewentualnie wyłączając teleonomiczne zachowania istot żywych) i wartości wewnętrznej. Goldsmith uznaje ów paradygmat nowożytnego przyrodoznawstwa za błędny, kryzysotwórczy i uniemożliwiający prawidłową, zdrową relację ludzkości z całą ekosferą. Za paradygmatem tym stoi określone rozumienie postępu ludzkości oraz konkretne założenia ontologiczne, aksjologiczne i etyczne.

Jeśli chodzi o te ostatnie Goldsmith, podobnie jak wielu przyrodników ${ }^{1}$ uznaje, że etyka stanowi wynik procesu adaptacji

1 Goldsmith przywołuje m.in. Conrada H. Waddingtona i Juliana Huxleya, warto wymienić ponadto także Edwarda O. Wilsona (Wilson 2002), Robina Dunbara (Dunbar 2014) czy Fransa de Waala (de Waal 2016). gatunku ludzkiego w toku filogenezy. Przyjmuje zatem tzw. etykę naturalistyczną, zgodnie z którą normy i wartości moralne to pozagenetyczne, kulturowe wytyczne regulujące relacje międzyludzkie oraz ze światem w ogóle. Uznaje również, że pewne wartości moralne muszą być stałe, niezmienne, gdyż w przeciwnym wypadku grupy społeczne nie mogłyby zachowywać ani kontynuacji, ani stabilności. Nie mogłyby też przejawiać zachowań służących podtrzymywaniu porządku Kosmosu - charakterystycznych przynajmniej dla społeczności pierwotnych. Goldsmith uważa, że informacja zawarta w ludzkich strukturach poznawczych została uprawomocniona przez sam proces ewolucyjny, gdyż została uformowana przez konieczność radzenia sobie w środowisku. Przyroda stanowi zatem swoisty „autorytet akceptujący”, który uznaje poszczególne instrukcje i przyjmuje konkretne zasady etyczne kierujące zachowaniem. Zasady te są sankcjonowane, uwierzytelniane, uprawomocniane i gwarantowane przez przyrodę, której integralną część człowiek stanowi, i której praw musi przestrzegać, aby przetrwać. W tym ujęciu zachowaniami moralnymi są tylko te, które uzdalniają istoty żywe do postępowania zgodnie z prawami i ograniczeniami przyrody oraz do zachowywania się jak jej immanentny element. Ostatecznie więc to sam proces życia na Ziemi zapewnia najlepszy przewodnik etycznego postępowania (Web-04).

Uzasadniając podporządkowanie ludzi przyrodzie w relacji „elementy składowe całość", Goldsmith powołuje się m.in. na badania Jeana Piageta w zakresie psychologii dziecka i psychologii wychowawczej. Szwajcarski psycholog zauważył mianowicie, że w umysłowym rozwoju dziecka istotną rolę odgrywa poczucie respektu małego wobec wielkiego (Web-04). W pewnym sensie przytoczona analogia może potwierdzać holistyczne intuicje Goldsmitha.

Nie wszyscy zwolennicy etyki ewolucyjnej widzą moralność w podobny sposób jak Edward Goldsmith. Wśród nich wymienić należy tzw. społecznych darwinistów, 
jak Herbert Spencer, Thomas H. Huxley, George Gaylord Simpson, Jacques Monod, Edward Osborne Wilson, Richard Dawkins. Autorzy ci głoszą etykę indywidualizmu (w przeciwieństwie do integracji), współzawodnictwa, egoizmu i agresji, która, ich zdaniem, jest zgodna z "prawem naturalnym”. Świat postrzegany przez nich jawi się jako przypadkowy, chaotyczny, zatomizowany, zmuszający do konkurencji i agresywny, pozbawiony bardziej podstawowego aspektu współpracy (Web-04). Dla G.G. Simpsona i J. Monoda najbardziej znaczącym aspektem przyrody jest jej przypadkowość i bezcelowość (obrazowo wyrażona w znamiennym tytule dzieła Monoda Przypadek i konieczność; por. Monod 1979). Skutkuje to przekonaniem, że nie ma żadnych uniwersalnych, wiecznych czy absolutnych kryteriów moralnego dobra i zła, nie jest możliwe odnalezienie jakiejś intuicyjnej etyki, nawet uniwersalizm etyki naturalistycznej staje pod znakiem zapytania. To człowiek, świadomy, rozumny i wolny, jest twórcą etyki - jej podstawę stanowi zaś wiedza: "obiektywna” i „naukowa” (Web-04).

Szkocki myśliciel i filozof, Adam Smith (1723-1790) ukazał w swej pracy Badania nad natura $i$ przyczynami bogactwa narodów (Smith 1776), że poprzez egoistyczne zachowania możliwe jest zwiększanie nie tylko naszych osobistych materialnych profitów, ale także korzyści dla całego społeczeństwa. Myśl ta podchwycona została następnie przez teoretyków utylitaryzmu etycznego: Jeremy'ego Benthama (Bentham 1789) i Johna Stuarta Milla (Mill 1863), którzy zracjonalizowali indywidualizm i egoizm. Goldsmith podkreśla, że wprowadzenie w życie wspomnianych teorii ekonomicznej i etycznej poskutkowało groźbą rozpadu społeczeństw zarówno czasów rewolucji przemysłowej, jak i współczesnych. Ale, co istotniejsze dla niniejszych rozważań, tak pojmowana etyka legitymizowała, racjonalizowała i uprawomacniała postęp (Web-o4). Warto wspomnieć też o roli darwinizmu w tym procesie. Otóż niemiecki filozof kultury i historii, Oswald Spengler (1880-1936) określił darwinizm jako zastosowanie ekonomii do biologii, zaś darwinowską selekcję naturalną jako biologiczną wersję niewidzialnej ręki rynku A. Smitha. Jako taki darwinizm uprawomocnił postęp gospodarczy i społeczny jako proces zgoła naturalny (Por. Web-o3). Z tak pojętego postępu swe źródło czerpie cała technosfera, określana przez Goldsmitha mianem „zastępczego świata wytworów ludzkich”. Współcześnie postęp jest rozumiany jako proces celowy, inspirowany racjonalnym namysłem i bazujący na obiektywnej wiedzy. W konsekwencji człowiekowi naszych czasów wydaje się, że wszystkie korzyści czerpie z technosfery raczej niż z biosfery, i że postępowanie etyczne to takie, które wiedzie do ekonomicznego wzrostu i maksymalnego rozwoju technosfery. Goldsmith nazywa etykę stojącą za tymi przekonaniami etyką technosferyczną i przeciwstawia jej etykę biosferyczną, która dla kontrastu racjonalizuje i uprawomocnia ochronę oraz zachowanie przyrody, od której ostatecznie zależy nasze przeżycie (Web-04).

\section{Krytyka nowożytnego paradygmatu naukowo-technicznego}

W artykule Towards a Biospheric Ethics (Web-04) Edward Goldsmith poddaje krytyce zasadnicze założenia nowożytnego paradygmatu naukowo-technicznego. Proces uzasadniania tezy, że paradygmat ten jest błędny i nie do zaakceptowania, zaczyna od zakwestionowania twierdzenia, że tylko człowiek współczesny jest zdolny do zachowań moralnych. Wskazuje, że przekonanie to stanowi element mitu lub nawet dogmatu o postępie, który wyniósł człowieka ponad przyrodę. Jeśli za postępowanie moralne uznać zachowanie miłosierne, altruistyczne czy życzliwe - to, zdaniem Goldsmitha, brakuje jakichkolwiek dowodów na to, że pozaludzkie zwierzęta nie postępują w sposób moralny (Web-04). Goldsmith powołuje się tu na badania Konrada Lorenza (Por. Lorenz 1972), który opisuje tego typu zachowania, jakkolwiek postrzegając je, w przeciwieństwie do Goldsmitha, nie jako moralne sensu 
stricto, lecz jako analogiczne do prawdziwej moralności.

Kolejne kwestionowane przez Goldsmitha twierdzenie mówi o tym, że tylko człowiek jest zdolny do zachowań celowych. Goldsmith uznaje je za dogmat, który usprawiedliwia, że tylko człowiek działa w sposób moralny oraz który racjonalizuje proces postępu, mający polegać na przekształcaniu przypadkowego, chaotycznego świata w uporządkowany i celowy. Jego zdaniem, im więcej wiemy o biosferze, tym bardziej uporządkowana i celowa się nam jawi i tym trudniej podtrzymywać tezę o jej przypadkowości (Web-o4).

Trzecie odrzucane twierdzenie racjonalizujące postęp uznaje, że postępowanie człowieka współczesnego bazuje przede wszystkim na świadomym wyborze, a nie na przekonaniu czy wierze. Nie ma dowodu na to, że jedynie człowiek dokonuje świadomych wyborów. Goldsmith zauważa, że świadome wybory, zarówno u człowieka, jak i innych istot żywych, są w dużej mierze iluzoryczne. Badania nad motywacją ujawniają, że powody podawane przez ludzi dla wyjaśnienia ich postępowania są w większości racjonalizacjami, mającymi na celu przekonanie, że oparte były na świadomych i racjonalnych przemyśleniach. Większość tzw. wolnych decyzji człowiek podejmuje pod wpływem przeróżnych determinant, spośród których wymienić należy emocje, pragnienia czy upodobania. Co więcej, utrzymywanie, że zachowanie jest etyczne tylko wówczas, gdy jest rezultatem świadomego wyboru, jest nie do pogodzenia $\mathrm{z}$ wizją etyki dostarczającej ogólnych, niemodyfikowalnych instrukcji zapewniających kontynuację albo stabilność wzorca zachowań w danym społeczeństwie. A gdyby jednak było - powstałby wysoce niestabilny wzorzec zachowań społecznych, który skutkowałby brakiem kontynuacji bądź stabilności danego społeczeństwa (Web-o4).

Kolejna odrzucana przez twórcę etyki biosferycznej teza głosi, że zachowanie etyczne musi faworyzować indywidualizację. Zatomizowana lub zindywidualizowana biosfera jest biosferą chorą, zdezintegrowaną - taką, jaką się staje pod wpływem rozwoju ekonomicznego i postępu. Zdrowa biosfera jest wysoce zorganizowana. Podobnie jest ze społeczeństwem: zatomizowane i zindywidualizowane jest społeczeństwem chorym. Wyalienowani członkowie takiego społeczeństwa tracą władzę panowania nas samymi sobą i muszą być rządzeni przez rząd i rozbudowaną biurokrację, której prawdopodobnie nie potrzebowaliby, gdyby żyli w społeczeństwie zdrowym i ustrukturowanym. Dlatego też, akcentuje Goldsmith, etyka indywidualizacji jest etyką ekologicznej i społecznej dezintegracji (Web-04).

Następnym przekonaniem, które krytykuje Goldsmith, jest założenie, że etyka musi być oparta na nas samych, a nie wywiedziona z czegoś większego niż my sami, np. ze społeczeństwa czy przyrody. Jego konsekwencją jest mniemanie, że człowiek może dowolnie kierować swoją ewolucją, nie musząc podporządkowywać się żadnym społecznym czy ekologicznym ograniczeniom. Pogląd ten zbieżny jest z poglądami neodarwinowskimi i socjobiologicznymi, gdzie człowiek jest egoistą, którego jedyną funkcją jest rozpowszechnianie własnych genów. Przywodzi na myśl także pogląd G. Simpsona i J. Monoda o człowieku wyobcowanym w przypadkowym świecie, w którym nie ma żadnej roli do spełnienia (Web-o4). Tymczasem w świecie wszystko jest ze sobą powiązane, zaś kooperacja stanowi niezbędny element funkcjonowania każdego systemu.

Goldsmith odrzuca wreszcie etykę naukowego, technicznego i przemysłowego postępu. Rozwój ekonomiczny zakłada systematyczne zastępowanie biosfery - naturalnego świata istot żywych, z której człowiek czerpie zasoby i do której wydala coraz większe ilości, coraz bardziej toksycznych odpadów - przez technosferę, czyli świat wytworzony przez człowieka. Nieuniknioną konsekwencją rozrostu technosfery jest dezintegracja i skurczenie biosfery. Wzrost ekonomiczny, jest $\mathrm{w}$ istocie miarą dezintegracji i skurczenia biosfery. Oba procesy są przeciwnymi stronami tego samego medalu. 
Etyka postępu, jak podkreśla Goldsmith, nie jest niczym innym jak etyką biosferycznej destrukcji. To nie jest etyka ewolucyjna przeciwnie, to etyka anty-ewolucyjna (Web-04).

Krytykowana przez Goldsmitha etyka postępu i nieustannej technicznej ekspansji zakłada, że moralność zaczyna się wraz z człowiekiem współczesnym i nie można mówić o człowieku pierwotnym czy o innych istotach żywych, jako moralnych. Podobnie rzecz ma się ze świadomością, wolnością wyboru, rozumnością, wiedzą i celowością, bez których moralności nie ma i być nie może. J. Huxley mówi wprost o jednostce ludzkiej jako najwyższym wytworze ewolucji, któremu jako jedynemu dostępne są wartościowe wewnętrznie doświadczenia miłości, piękna, wiedzy, mistycznego zjednoczenia. Człowiek jest jedynym źródłem wartości w świecie. Człowiek jest kreatorem świata (deifikacja człowieka) (Web-o4). Tymczasem wszelkie zdolności człowieka nie wzięły się z próżni; bazują na wypracowanych filogenetycznie zdolnościach, które w różnym stopniu nasilenia są obserwowane także u przedstawicieli innych gatunków niż ludzki i które musiały występować także u przodków człowieka współczesnego (por. de Waal 2016).

Goldsmith podkreśla, że poważne problemy ekologiczne, z którymi się dzisiaj mierzymy, mogą się tylko pogłębić w ramach wysoce konkurencyjnej globalnej ekonomii, która ze swej natury może zostać zdominowana jedynie przez nieliczące się z niczym i nikim międzynarodowe korporacje. Jedynym wyjściem z tej sytuacji, jego zdaniem, jest stworzenie zupełnie nowej ekonomii światowej - bardziej lokalnej, dużo mniej konkurencyjnej, w której możliwe będzie przeprowadzenie wszystkich wymaganych zmian dla zachowania warunków do życia człowieka na Ziemi (Web-o2).

Goldsmith zdaje sobie sprawę, że zmiana obrazu świata, współcześnie obowiązującego paradygmatu, jest bardzo trudna. Ludzie i całe społeczeństwa dysponują mechanizmami podtrzymującymi spójność przyjmowanego światopoglądu i broniącymi przed jakimikolwiek informacjami, które mogłyby nim zachwiać (zasada ochrony struktury kognitywnej). Jednak przyjmując taki wykoślawiony obraz świata nigdy nie będziemy w stanie poprawnie interpretować problemów zagrażających naszemu przeżyciu, opracować koniecznej polityki powstrzymującej niszczycielski wpływ cywilizacji na planetę, ani rozwinąć udanego i niedestrukcyjnego sposobu życia (Web-o3).

\section{Etyka biosferyczna Edwarda Goldsmitha}

Goldsmith uważa, że w pierwotnych społecznościach ludzkich etyka sprzyjająca realizacji celów Gai, czyli tzw. etyka homeoteliczna wobec Gai, była czymś oczywistym. Ludzie żyjący w plemionach przepojeni byli światopoglądem, który pozwalał im postrzegać podtrzymywanie „kosmosu” (gr. cosmos porządek) jako fundamentalnego obowiązku i wzoru zachowań, szczególnie w obszarze rytuałów i życia religijnego. Kosmos w rozumieniu ludzi myślących kategoriami mitycznymi stanowił jedność społeczeństwa, środowiska naturalnego oraz świata bóstw. Zachowanie porządku było warunkiem sine qua non przeżycia oraz dobrostanu (Web02). Te podstawowe zasady budujące światopogląd pierwotnych społeczności, jak podkreśla religioznawca Mircea Eliade, były wszędzie takie same. Tradycyjne społeczeństwa w pełni rozumiały, że porządek jest podstawową cechą hierarchii Gai. Wszystko: ciało, dom, świątynię, wspólnotę społeczną, środowisko naturalne oraz sam Kosmos postrzegały jako zorganizowane według tego samego planu, jako rządzone tymi samymi prawami i z tego względu stanowiące jedną zorganizowaną całość (Web-o3). Współczesny, oświecony człowiek, wraz z nauką i technologią, poniósł zaś fiasko w zrozumieniu tych zależności.

Odnosząc się do tego, jak pierwotnie człowiek realizował swą relację ze światem, Goldsmith przekonuje, że skutecznie chronić porządek ekosfery (lub Kosmosu) można wyłącznie w sposób religijny (Web-o3). Nowożytny paradygmat naukowo-techniczny 
nie pozwala na jakiekolwiek odstępstwa od naukowej ortodoksji. Nie porzucił zatem wiary religijnej. Tradycyjną religijność zastąpił scjentystyczną wiarą w naukę i w to, że nauka zbawi ludzkość. Ekologia, która powinna, zdaniem Goldsmitha, zastąpić ów błędny paradygmat, także jest wiarą. Z tym, że jest to „wiara w mądrość tych sił, które stworzyły przyrodę oraz kosmos (...); to wiara w zdolność przyrody do zaopatrywania nas w wyjątkowe korzyści - wymagane dla zaspokojenia naszych najbardziej podstawowych potrzeb. To wiara w naszą zdolność do rozwijania takich wzorców kulturowych, które uzdolnią nas do podtrzymywania jej integralności i stabilności" (Web-o1).

Etyka biosferyczna, zgodna z ekologicznym spojrzeniem na świat, w którym żyjemy, jest zupełnie odmienna od proponowanej przez współczesnych rzeczników postępu. Przede wszystkim etyka ta stwarzałaby odpowiednie warunki, aby człowiek mógł uczestniczyć w osiągnięciu naczelnego celu Gai: podtrzymywania stabilności lub homeostazy biosfery w obliczu zmian. Takie działania (homeoteliczne) byłyby uznawane w niej za moralne dobre. $Z$ kolei działania zmniejszające homeostazę Gai, czyli heteroteliczne, byłyby niemoralne, gdyż zakłócałyby podstawową strukturę Kosmosu (Web-04).

Taka etyka, zdaniem Goldsmitha, funkcjonowała w pierwotnych społecznościach ludzkich w przeszłości. Prawa w nich obowiązujące nie tylko pochodziły od przodków, ale też miały na celu podtrzymywanie porządku w świecie, Kosmosie. I dopóki ten porządek trwał, dopóty człowiekowi się wiodło, gdy był zakłócany, wówczas nieuchronnie nadchodziła katastrofa. Dlatego też fundamentalną rolą życiową człowieka było dbać o podtrzymywanie kosmicznego ładu. Zadanie to wypełniał m.in. za pośrednictwem przeprowadzanych rytuałów, poprzez uczestniczenie w odpowiednich ceremoniałach oraz przestrzeganie tradycyjnych praw, które dotyczyły nie tylko ładu w grupie społecznej, ale i w samym
Kosmosie. W wielu społecznościach ów wzorzec etycznego postępowania odnoszony był do słowa, które określało zarówno ład kosmiczny, jak i ścieżkę czy drogę, którą należy podążać, aby ten ład utrzymać. Droga ta jest jedyną prawdziwie moralną, gdyż zapewnia dobrostan wszystkich istot żywych. Odwrócenie się od niej, zejście z niej wywołuje natomiast rozmaite katastrofy, takie jak powodzie, susze, nieurodzaj, epidemie, bezpłodność czy wojny. Czyny niezgodne z Drogą stanowią w społeczności tabu. I chociaż nie każdy lud miał rozumienie Drogi sformułowane tak explicite, to pojmowanie moralności pozostawało wszędzie podobne (Web-o4).

Patrząc na współczesną cywilizację przez pryzmat kryterium Drogi, która stała się też tytułem najbardziej znanej książki Goldsmitha - The Way: An Ecological Worldview (Goldsmith 1992) - nie ma bardziej niemoralnego przedsięwzięcia niż postęp, który wiedzie systematycznie do zastąpienia biosfery przez technosferę. Rozwój ekonomiczny prowadzi w sposób nieunikniony do destrukcji świata istot żywych. W rzeczywistości katastrofy naturalne, które spotykają nas coraz częściej, są właśnie symptomami tej destrukcji. Są ceną, jaką płacimy za niemoralność polityki gospodarczej. Dlatego jedyną moźliwością, aby zmniejszyć te problemy, jest porzucenie dotychczasowej polityki i poszukiwanie sposobu, w jaki moglibyśmy to, co jeszcze możliwe, naprawić. Jeśli chcemy przetrwać jako gatunek - podkreśla Goldsmith - musimy powrócić do Drogi. Nie ma innego wyjścia, jak powrócić do etyki biosferycznej, która tak wiernie odzwierciedla Drogę (Web-o4).

\section{Kontrowersyjność etyki biosferycznej}

Interesująca propozycja etyki środowiskowej opracowana przez Edwarda Goldsmitha daje wyraz holistycznemu ujęciu relacji człowieka ze światem. Opierając etykę biosferyczną na bazie kontrowersyjnej Hipotezy Gai Jamesa Lovelocka, Goldsmith nie uniknął związanych z nią trudności. Wysunięta przez Lovelocka koncepcja doczekała 
się bowiem szeregu głosów krytycznych ze strony przyrodników głównego nurtu.

Tym, co jako pierwsze stanowiło obiekt ataku, była sama nazwa nadana żyjącej planecie - Gaja. Została ona odebrana jako mglista i niedopuszczalna ekspresja mitu, metafora, nawiązanie do duchowości a nawet nurtu New Age, które zostały w sposób nieuprawniony wniesione na grunt prostych, surowych faktów oraz ugruntowanych naukowych teorii. Uznano, że akt ten doprowadził do odnowienia zarzuconych w nowożytności animistycznych wizji Ziemi. Potraktowano go jako profanację dostojnego gmachu współczesnej nauki. Neodarwinizm potępił z całą surowością nieuzasadnioną implikację, zgodnie z którą życie, jako zunifikowana całość, miałoby posiadać cel. W przyrodzie jako takiej nie ma bowiem celowości. Skoro zaś życie nie posiada celu, to jak mogłoby działać dla własnego trwania? (Crist, Rinker 2010: 7-9)

Krytycy zarzucają, że najprawdopodobniej to nie organizmy kształtują środowisko, aby sprzyjało ich trwaniu. Takie przekonanie jest raczej swego rodzaju złudzeniem wynikającym z faktu, że wszystkie obecnie żyjące organizmy są do współczesnego środowiska przystosowane, są „zwycięzcami” w walce o byt. Pogląd ten jednak jakby zapominał o tym, że wszystkie pozostałe gatunki w tej walce poległy i wyginęły. To nie środowisko zostało skrojone do potrzeb organizmów, ale przetrwały te, które były najlepiej przystosowane do środowiska (Kirchner 2002: 392). Selekcja naturalna faworyzuje organizmy, które najlepiej wykorzystują środowisko. Organizmy czerpią zatem korzyści ze środowiska nawet wówczas, gdy nie zostało ono skrojone do ich potrzeb (Kirchner 2002: 399).

Inne krytykowane założenie Hipotezy Gai zakłada, że biologiczne sprzężenia zwrotne mają znaczenie stabilizujące i to za ich pomocą organizmy zmieniają otoczenie dla własnej korzyści. Wiele danych empirycznych zaprzecza biologicznie osiąganej homeostazie (Kirchner 2002: 398). James Kirchner zwraca uwagę, że u Lovelocka doszło do pomylenia ze sobą negatywnych i pozytywnych sprzężeń zwrotnych: za negatywne sprzężenie zwrotne Lovelock uznaje sytuację, gdy organizmy zmieniają swoje środowisko, aby bardziej odpowiadało ich potrzebom. Jednak wówczas, zauważa Kirchner, istoty żywe rozwijają się i oddziałują na środowisko jeszcze bardziej, co pozwala im nadal wzrastać i coraz mocniej oddziaływać na środowisko. Jest to więc bezsprzecznie pozytywne sprzężenie zwrotne. $\mathrm{Z}$ ujemnym sprzężeniem zwrotnym mamy do czynienia natomiast w sytuacji odwrotnej: gdy wzrastająca populacja czyni swe środowisko coraz bardziej niekorzystnym dla siebie, co ogranicza jej wzrost. Sprzężenia poprawiające środowisko (environment-enhancing feedbacks) są więc ostatecznie destabilizujące, natomiast sprzężenia degradujące środowisko (environment-degrading) są stabilizujące (Kirchner 2002: 404).

Te same zarzuty, co wobec Hipotezy Gai, można skierować wobec założeń etyki biosferycznej, której uzasadnienie opiera się na koncepcji głoszącej, że człowiek i świat stanowią jedność, zaś człowiek jest elementem systemu ziemskiego bezpośrednio mu podporządkowanym. Faktycznie, bezpośrednie podporządkowanie części całemu systemowi funkcjonuje w przyrodzie pozaludzkiej. Tyle że gatunek ludzki, ze względu na swą specyfikę (chodzi zwłaszcza o takie cechy, jak złożona struktura społeczna, rozumność, tworzenie kultury), nie do końca wpisuje się w ten schemat. Rozwój kultury ludzkiej potwierdza, że zachodzące w niej zmiany zmierzają w kierunku stawiania człowieka w coraz większej opozycji wobec natury oraz pogłębiania separacji od niej. Indywidualne i zbiorowe działania człowieka stają się więc w tym procesie coraz bardziej heteroteliczne względem ekosfery (tzn. sprzeczne z jej nadrzędnym celem, jakim jest kontynuacja istnienia życia). Pomimo to, ponieważ realizują bezpośrednie dyrektywy systemu społecznego, są (zgodnie z koncepcją Goldsmitha) nadal moralnie słuszne, choć stanowią rezultat niewłaściwego z punktu widzenia biosfery określenia celów człowieka na poziomie 
kulturowym. Skoro jednak etyka, jak wskazuje Goldsmith, jest wytworem ewolucji, to ten stan rzeczy powinno się uznać za naturalny (Bonenberg 1992: 105-106). Gdyby człowiek podejmował decyzje o niepodporządkowaniu się systemowi społecznemu w celu realizowania dobra systemu nadrzędnego - czyli biosfery, wówczas należałoby uznać człowieka za wyjątkowy element przyrody, i/lub społeczeństwo za twór sztuczny, np. wynik tzw. umowy społecznej.

Zdaniem Marka Bonenberga, homeoteliczne zachowania indywidualnych osób i zbiorowości wobec biosfery mają walor moralny nie dlatego, że służą bezpośrednio dobru biosferycznej całości. Powód jest bardziej prozaiczny: człowiek jest powiązany z całym systemem biosfery, zaś jego destrukcja grozi katastrofalnymi konsekwencjami dla samego gatunku ludzkiego. Powinności moralne są więc $\mathrm{w}$ istocie powinnościami wobec obecnych oraz przyszłych pokoleń ludzkich, a to oznacza, że etyka biosferyczna jest zbieżna z tradycyjnymi poglądami antropocentrycznych systemów etycznych $i$ jest w gruncie rzeczy etosem przetrwania (Bonenberg 1992: 108).

Inna trudność etyki biosferycznej wiąże się z przyjmowanym założeniem o istnieniu równowagi w przyrodzie i warunkującego ją „kosmicznego” ładu, obecnie naruszanego przez człowieka. Niewątpliwie to, co się wydarza w przyrodzie pozostaje w zgodzie z prawami natury. Jako taki Wszechświat jest uporządkowany i „przewidywalny”. Mimo to pełen jest zjawisk zaburzających ową mityczną równowagę, co odnosi się również do sytuacji spotykanej na Ziemi. Rzeczywiście, ziemskie życie rozwija się we w miarę stabilnych warunkach w porównaniu do wielu innych stanów obserwowanych we Wszechświecie i wyłącznie dzięki temu wciąż istnieje. Niemniej homeostaza wielokrotnie była naruszana w historii życia na Ziemi bez udziału człowieka, np. zmiany natężenia promieniowania docierającego do powierzchni planety, perturbacje jej orbity, upadki wielkich meteorytów, drastyczne zmiany klimatyczne, zmiany w składzie atmosfery, wymieranie większości gatunków zwierząt i roślin. Zjawiska te nie doprowadziły jednak do tak daleko idących zmian, które uniemożliwiałyby przetrwanie i rozwój jakichś form życia, ewoluujących i przystosowujących się do nowej sytuacji (Bonenberg 1992: 93-95). Także człowiek nie jest w stanie zniszczyć całkowicie ciągłości życia na Ziemi, mimo że skutkiem jego działalności są poważne i bardzo niekorzystne zmiany dla zdrowia i istnienia ekosystemów.

W tym kontekście warto zauważyć, że cechą charakterystyczną większości etyk środowiskowych jest przypisywanie człowiekowi określonych powinności moralnych wobec przyrody. Zaś określenie katalogu tych powinności zależy od naszej aktualnej wiedzy ekologicznej. Pokazuje to, że de facto nasze moralne zobowiązania są zrelatywizowane do poziomu naszej wiedzy na temat funkcjonowania przyrody na jej rozmaitych poziomach. Postęp w zakresie tejże wiedzy może postawić pod znakiem zapytania pewne dotychczasowe postulaty dotyczące relacji człowieka do przyrody, może też otworzyć przed ludzkością nowe wymiary odpowiedzialności. Kwestia ta przywodzi z kolei na myśl problematykę błędu naturalistycznego: aby go uniknąć nie powinno się utożsamiać tego, co się dzieje w przyrodzie (faktów), z tym, jak być powinno (dobro i powinność moralna).

Jednak najbardziej chyba kontrowersyjną tezą Goldsmitha jest ta mówiąca, iż to nowożytny paradygmat postępu naukowo-technicznego jest winien kryzysowi ekologicznemu, wcześniej bowiem człowiek żył w harmonii z przyrodą. Twierdzenie to stanowi wyraz dość popularnego w kręgach enwironmentalistów „mitu szlachetnego dzikusa”. Zgodnie z nim człowiek ze swej natury skłonny jest do kształtowania harmonijnych relacji z przyrodą oraz drugim człowiekiem. Bez wątpienia taka wizja natury ludzkiej jest atrakcyjna, ukazuje bowiem człowieka jako dobrego i szlachetnego. Wiele wydaje się jednak wskazywać na to, że jest ona nieprawdziwa i niezgodna ze współczesną wiedzą na temat natury człowieka i stylu jego 
aktywności w świecie. Liczne badania prowadzone w różnych zakątkach świata potwierdzają, że człowiek od początku swego istnienia niszczył przyrodę - niezależnie od epoki, religii i kultury, z której się wywodził (Sadowski 2016: 27). Niszczące nadużywanie zasobów środowiska od bardzo dawna jest motorem ludzkiej historii. Odkrycia archeologów pokazują, że społeczeństwa preindustrialne - podobnie jak dzisiejsze - również przyczyniały się do zachodzenia poważnych zmian i degradacji w środowisku oraz do ginięcia innych gatunków. Dostrzegalne współcześnie nasilenie się tego typu procesów wynika stąd, że współczesna technika dysponuje znacznie większym potencjałem niszczącym, niż tysiące lat temu oraz - że nastąpił ogromny przyrost liczby ludności (Diamond 1996: 425-426, 476).

\section{Zakończenie}

Przeprowadzona przez Edwarda Goldsmitha krytyka nowożytnego paradygmatu postępu naukowo-technicznego prowadzi do wniosku, że jest on błędny, kryzysotwórczy i uniemożliwia prawidłową, zdrową relację ludzkości z biosferą. Goldsmith odrzuca ściśle powiązaną z tym paradygmatem etykę postępu, która de facto stanowi etykę biosferycznej destrukcji, prowadzącą do wytworzenia technosfery, czyli „zastępczego świata” wytworów ludzkich. Goldsmith krytykuje również dominujący we współczesnej etyce paradygmat utylitarystyczny, który racjonalizuje i faworyzuje indywidualizm i egoizm. Tymczasem zarówno zatomizowana i zindywidualizowana biosfera jest biosferą chorą oraz zdezintegrowaną, jak i zatomizowane i zindywidualizowane społeczeństwo jest społeczeństwem chorym oraz zdezintegrowanym. Zdrowa biosfera jest wysoce zorganizowana. Podobnie zdrowe społeczeństwo musi być uporządkowane i spójne. W biosferze wszystko jest ze sobą powiązane, kooperacja stanowi natomiast nieodzowny element funkcjonowania wszystkich systemów. Jedynym wyjściem dla uratowania ludzkości przed grożącą jej ekologiczną samozagładą jest odrzucenie paradygmatu naukowo-technicznego wraz z kreowanym przez niego postępem i technosferą, a powrócenie do harmonijnego współistnienia ze światem, gdzie wartością najwyższą i najważniejszym celem jest dobro całej wspólnoty istot żywych na Ziemi.

\section{Bibliografia}

Bentham J., 1789, An Introduction to the Principles of Morals and Legislation, Clarendon Press, Oxford (wydanie polskie: Bentham J., 1958, Wprowadzenie do zasad moralności i prawodawstwa, tłum. Bogdan Nawroczyński, Państwowe Wydawnictwo Naukowe, Warszawa).

Bertalanffy L. von, 1984, Ogólna teoria systemów. Podstawy, rozwój, zastosowania, tłum. E. Woydyłło-Woźniak, PWN, Warszawa.

Bonenberg M. M., 1992, Etyka środowiskowa. Zatożenia i kierunki, Wydawnictwo UJ, Kraków.

Crist E. i H. B. Rinker, 2010, One Grand Organic Whole, in: Crist E. i Rinker H. B. (ed.), "Gaia in Turmoil. Climate Change, Biodepletion, and Earth Ethics in an Age of Crisis", The MIT Press, Cambridge, Massachusetts, London, England, 3-20.

Dawkins R., 1996, Samolubny gen, tłum. M. Skoneczny, Prószyński i S-ka, Warszawa.

Diamond J., 1996, Trzeci szympans, tłum. J. Weiner, PIW, Warszawa.

Dunbar R., 2014, Nowa historia ewolucji człowieka, tłum. B. Kucharczyk, Copernicus Center Press, Kraków.

Goldsmith E., 1992, The Way: An Ecological Worldview, Rider Books, London.

Kirchner J. W., 2002, The Gaia Hypothesis: Fact, Theory, and Wishful Thinking, "Climatic Change" Vol. 52, 391-408.

Lorenz K., 1972, Tak zwane zło, tłum. A. Tauszyńska, PIW, Warszawa.

Lovelock J., 2003, Gaja. Nowe spojrzenie na życie na Ziemi, tłum. M. Ryszkiewicz, Prószyński i S-ka, Warszawa.

Mill J. S., 1863, Utilitarianism, Son, and Bourn, London (wydanie polskie: Mill J. S., 2005, Utylitaryzm, tłum. M. Ossowska, Wydawnictwo Naukowe PWN, Warszawa).

Monod J., 1979, Przypadek i konieczność, tłum. J. Bukowski, Biblioteka Głosu, Warszawa.

Næss A., 1973, The Shallow and the Deep, long-range ecology movement. A summary, "Inquiry: 
An Interdisciplinary Journal of Philosophy and the Social Sciences" 16, 95-10o.

Sadowski R.F., 2016, The Concept of «Nobilis Barbarus» in the Light of Contemporary Ecological Challenges, "Problems of Sustainable Development" Vol. 11, No 1, 23-30.

Smith A., 1776, An Inquiry into the Nature and Causes of the Wealth of Nations, W. Strahan and T. Cadell, London (wydanie polskie: Smith A., 2007, Badania nad natura i przyczynami bogactwa narodów. Tom 1 i Tom 2, tłum. S. Wolff, O. Einfeld, Z. Sadowski, A. Prejbisz, B. Jasińska, Wydawnictwo Naukowe PWN, Warszawa).

Waal de F., 2016, Bonobo i ateista. W poszukiwaniu humanizmu wśród naczelnych, tłum. K. Kornas, Copernicus Center Press, Kraków.

Wilson E. O., 1999, Różnorodność życia, tłum. J. Weiner, PIW, Warszawa.
Wilson E.O., 200o, Socjobiologia, tłum. Mariusz Siemiński, Wydawnictwo Zysk i S-ka, Poznań.

Wilson E.O., 2002, Konsiliencja. Jedność wiedzy, tłum. J. Mikos, Zysk i S-ka, Warszawa.

(Web-01) Goldsmith E., Ecology is a faith, < http:// www.edwardgoldsmith.org/1084/>, data dostępu: 07.06.2013.

(Web-02) Goldsmith E., Ecology - a bridge, http:// www.edwardgoldsmith.org/737/ecology-a-bridge, data dostępu: 7.6.2013.

(Web-03) Goldsmith E., The Way - a synthesis, http:// www.edwardgoldsmith.org/937/the-way-a-synthesis, data dostępu: 7.6.2013.

(Web-04) Goldsmith E., Towards a Biospheric Ethics, http://www.edwardgoldsmith.org/26/ towards-a -biospheric-ethic, data dostępu: 7.6.2013.

\section{Edward Goldsmith's Criticism of the Modern Paradigm of the Scientific and Technological Progress}

\section{Summary}

Environmental ethics finds many of its proponents among philosophizing naturalists. Interesting attitude is presented by Edward Goldsmith, who built a biospheric ethics based on the Gaia Hypothesis by James Lovelock. Goldsmith criticizes the Modern scientific paradigm. He perceives it as false and critical-creative for the relation of the humankind with ecosphere. Behind that paradigm states specific way of understanding of progress and particular ontological, axiological and ethical assumptions (ex. social Darwinism and ethical utilitarianism). Goldsmith calls ethics which covers those convictions a 'technospheric' ethics. He submits assumptions of this ethical attitude for criticism and oppose it to a biospheric ethics. According to the author, ethics that creates favourable conditions for achieving Gaia's goals was natural for primitive human societies. This ethics required from human to keep a cosmic order - that is wellbeing of individuals as well as the whole community. It assumed to follow an appropriate Way, which depends on respecting definite duties and behaviour, especially in the field of rituals and religious life. Therefore, as Goldsmith convinces, one can protect effectively the ecospheric order only in a religious way. In his opinion, does not exist more immoral venture than progress, which systematically leads to replacement of the biosphere by technosphere. The progress based on the technics leads inevitably to destruction. If we want to survive as a species - we need to return to the biospheric ethics.

\section{Key words}

environmental ethics, ecocentrism, holism, biosphere, human, Edward Goldsmith, Gaia Hypothesis 